\title{
O ESPETÁCULO DA VIDA HUMANA EM CATO MAIOR DE SENECTUTE
}

\author{
Isabella Tardin Cardoso ${ }^{\star}$ \\ Universidade Estadual de Campinas/ Fapesp/ Alexander von Humboldt Stiftung ${ }^{7}$
}

\begin{abstract}
The dialogue Cato Maior (De senectute) is often considered the Ciceronian text in which the topos of the "theater of life" (theatrum mundi) is explicitly revealed most frequently (five of the eight times in which it apears in all of the works of this author). Little attention, however, has been given to the effects of this topos on the dialog itself. It has been treated as a mere embellishment (ornatus), e.g. a resource used occasionally to apeal to more popular tastes. However, this article intends, firstly, to show that the theatrum mundi is an integral part of this philosophical dialogue; secondly, to provide a reflection on the theatricalization of the Cato Maior, suggesting philosophical effects arising from the use of the topos.
\end{abstract}

KEYWORDS: Cato Maior (De senectute); theatrum mundi; Cícero; Stoicism; Scepticism.

\footnotetext{
^icardoso@unicamp.br

${ }^{1}$ O presente texto é uma versão, levemente alterada, da exposição proferida na "VII Semana de Pós-graduação em Estudos Clássicos e Medievais” da FALE-UFMG em 10/12/2008 e, uma semana antes, em colóquio no Seminar für Klassische Philologie da Universidade de Heidelberg (Alemanha). Uma versão anterior foi apresentada no "IX Colóquio Internacional do Centro do Pensamento Antigo (CPA)" do IFCH-Unicamp (2007). As considerações aqui apresentadas integram uma pesquisa em andamento que trata mais amplamente do tópos do theatrum mundi na obra de Marco Túlio Cícero, a qual desenvolvo no Instituto de Estudos da Linguagem (IEL) da Unicamp, com o apoio, em diferentes etapas, da fundação Alexander von Humboldt ("Theatrum mundi in Ciceros Redekunst", 2006), da Fapesp ("Theatrum mundi em Cato Maior de Cícero", 2008; "A tragoedia em Pro Sestio de Cícero", 2010) e da Funcamp (estágio na Universität Wien, Áustria, em setembro de 2008). Além das pessoas e instituições mencionadas, agradeço, pelo gentil convite, especialmente
} 


\section{Introdução}

egundo a tradição, houve até mesmo uma ocasião em que, durante os jogos atenienses, certo senhor de idade chegara ao teatro e, em meio à grande audiência, lugar algum lhe havia sido concedido por parte de seus próprios concidadãos. Porém, quando ele chegou até os lacedemônios (que, na qualidade de embaixadores, se encontravam em assentos a eles reservados) conta-se que todos eles se levantaram para que o ancião tomasse lugar. E, quando, no momento em que se levantaram em conjunto, foram-lhes dados muitos aplausos, um dentre eles teria dito que os atenienses sabiam o que era correto, porém não o queriam fazer. ${ }^{2}$

E quando a artista começou a cortar sua própria carne com uma lâmina de barbear, era, literalmente, de se ouvir como os espectadores, diante do choque que tal ação desencadeou, prenderam a respiração. Quaisquer que fossem as transformações que os espectadores tenham sofrido durante aquelas duas horas - transformações que em parte se manifestavam por meio de perceptíveis expressões corporais - elas desembocaram na execução de ações perceptíveis por todos, que tiveram consequências perceptíveis por todos. Elas colocaram um fim à tortura da performer e, com isso, um fim à performance. Elas transformaram em atores os espectadores envolvidos. ${ }^{3}$

aos professores Tereza Virgínia Barbosa e Matheus Trevizam (FALE-UFMG), Jürgen Paul Schwindt (Universität Heidelberg) e, pela enriquecedora discussão, a todos os participantes.

${ }^{2}$ Cícero, Cato Maior 63-64: Quin etiam memoriae proditum est, cum Athenis ludis quidam in theatrum grandis natu venisset, magno consessu, locum nusquam ei datum a suis civibus; cum autem ad Lacedaemonios accessisset, qui legati cum essent certo in loco consederant, consurrexisse omnes illi dicuntur et senem sessum recepisse; quibus cum a cuncto consessu plausus esset multiplex datus, dixisse ex eis quendam, Atheniensis scire quae recta esset, sed facere nolle (Cícero, Cato Maior 63-64). A transcrição do texto latino de Cato Maior segue a edição oxfordiana de J. G. F. Powell (Cicero. De re publica; De legibus; Cato maior de senectute; Laelius de amicitia. Edited by J. G. F. Powell. Oxonii: e Typographeo Clarendoniano, 2006), a qual apresenta, segundo informa seu prefácio, poucas diferenças em relação ao texto estabelecido na edição comentada que o estudioso publicou em Cambridge em 1988 (cf. nota infra). A tradução para o português de textos em latim e em línguas modernas é, salvo outra indicação, de minha autoria. Quanto à versão da passagem específica, sou grata pelas sugestões a Paulo Sérgio de Vasconcellos (IEL-Unicamp).

${ }^{3}$ Cf. Fischer-Lichte, E. Ästhetik des Performativen. Frankfurt am Main: Suhrkamp, 2004, p. 12. 
A teatralização da vida, ponto em comum entre os dois textos acima transcritos, é o assunto que instiga a presente investigação acerca do primeiro deles, o diálogo filosófico Cato Maior (em português "Catão o Velho"), escrito por Marco Túlio Cícero (106-43 a.C.) no início do ano 44 a.C.

Em meio à produção remanescente do autor romano, é nesse diálogo que se costuma reconhecer como mais frequente a imagem da vida como um teatro: cinco vezes $(\mathbb{S} 5,48,64,70,85)$, dentre as oito ocorrências normalmente apontadas no conjunto da obra ciceroniana. ${ }^{5}$ Mas, embora se mostre tão enfaticamente no breve texto de Cato Maior, a representação do mundo como um palco não tem sido contemplada por estudos especificamente dedicados quer à sua presença, quer à sua influência nesse texto.

Talvez contribua para a existência dessa lacuna precisamente certo uso, digamos, inflacionado ${ }^{6}$ da ideia do "teatro do mundo" nos dias atuais: quer banalizada em formulações cotidianas da comédia ou tragédia da vida, quer constituindo objeto de estudos contemporâneos, nos mais diversos âmbitos culturais.

\footnotetext{
${ }^{4} \mathrm{Ou}$ em 45 a.C. Sobre a data, cf. discussões em Cicero. Cato Maior de senectute. Edited with introduction and commentary by J. G. F. Powell. Cambridge: University Press, 1988 (doravante mencionado como Cícero, op. cit., 1988), p. 1-3 e 267-68; Singh, K. L. On old age. In: MacKendrick, P. The philosophical books of Cicero. London: Duckworth, 1989, p. 353, n. 2.

${ }^{5}$ As outras três vezes em que o theatrum mundi é normalmente reconhecido na obra de Cícero são: uma vez em carta a seu irmão Quinto (Ep. ad. Quintus Fratrem I, 1, 46) datada de 60/59 a.C., uma em Os paradoxos dos estoicos (Paradoxa Stoicorum III, 26) e uma em Sobre os fins (De Finibus III, 15, 49). Cf. por exemplo Kokolakis, M. The dramatic simile of life. Athens: [Boukouris?], 1960, p. 28-31; Cícero, op. cit., 1988, p. 109. Os dois diálogos filosóficos (datados, respectivamente, de 46 e 45 a.C.) foram, tais como Catão o Velho, compostos no segundo e último período de produção filosófico-retórica de Cícero. Vale notar que, durante a pesquisa, uma atenção mais acurada ao tema do theatrum mundi leva a perceber no conjunto obra ciceroniana outras passagens em que a vida aparece como teatro, além das oito referidas em estudos dedicados à história da ideia. ${ }^{6}$ Agradeço a Flávio Ribeiro de Oliveira e Marcos Aurélio Pereira, colegas do IELUnicamp participantes da mesa no Congresso do CPA (ver nota 1), pelos comentários à comunicação oral que evidenciaram a necessidade dessa ponderação.

${ }^{7}$ Para o uso da metáfora do theatrum mundi em diversos títulos de livros científicos na época renascentista, cf. Blair, A. The theater of nature. Jean Bodin and renaissance science. Princeton (N.J.): Princeton University Press, 1997, p. 167; para uma sugestão quanto à sua presença na epistemologia de ciências modernas, cf. Cardoso, I. T. "Theatrum mundi”: Philologie und Nachahmung. In: Schwindt, J. P. (Org.). Was ist eine Philologische Frage? Frankfurt am Main: Suhrkamp, 2009, p. 82-111.
} 
Certamente, influi em nossa sensação de familiaridade no que concerne à imagem do teatro da vida sua longa história na cultura ocidental. Embora para muitos de nós a ideia talvez evoque mais diretamente obras renascentistas, como famosos versos de personagens shakespearianos, ${ }^{8}$ o mundo tem sido um palco ao menos desde o registro da ideia em diálogos de Platão ${ }^{9}$ (séc IV a.C.), a qual passaria a ser, ademais, muito difundida pelas filosofias helenísticas. Sua recorrência, com diversas nuanças e em obras de diferentes tipos, a torna um tópos filosófico e literário que é hoje denominado com uma expressão latina cunhada no século XII: ${ }^{10}$ theatrum mundi ("teatro do mundo").

No entanto, vale lembrar, é exatamente devido à ampla presença e variedade dos sentidos desse tópos que se mostra importante, no âmbito dos estudos clássicos, procurar situar com mais rigor seu significado, quando nos deparamos com o "teatro do mundo" em obras da Antiguidade. Um breve cotejo dos textos que introduzem o presente estudo pode tornar mais claro este ponto de vista.

No excerto de Erika Fischer-Lichte acima transcrito, comenta-se a dramática reação dos espectadores ${ }^{11}$ ao espetáculo Lips of Thomas da romena Marina Abramović, apresentado em 24 de outubro de 1975, na Galeria Krinziger (Innsbruck, Áustria). A semelhança entre o fenômeno descrito ali e no excerto do diálogo ciceroniano (Cato Maior 63-64) se mostra

\footnotetext{
${ }^{8}$ Para citar apenas a passagem provavelmente mais lembrada: expressões como "all the world is a stage" - do personagem Jacques na comédia As you like it (II, 7, v. 139, datada de 1599 ou 1600) - celebrizaram o tópos difundido mais amplamente na obra de W. Shakespeare. Cf., ainda, The merchant of Venice $(5.1,1,78)$; Macbeth $(2,4,6$; 5, 6, 180), entre outros.

${ }^{9}$ Por exemplo, em As Leis (VII 817B-D); Filebo (50B) e Apologia de Sócrates (35B). Cf. Kokolakis, op.cit., p. 11-12; Curtius, E. R. Europäische Literatur und lateinisches Mittelalter. Bern: Francke, 1948, p. 146; González García, J. M.; Konersmann, R. Theatrum mundi. In: Ritter, J.; Gründer, K. (Org.). Historisches Wörterbuch der Philosophie, vol. X, 1998, p. 1051-1054.

${ }^{10}$ A formulação theatrum mundi se registra pela primeira vez em 1159, mais propriamente na obra Policrático (Policraticus III, 9) de João de Salisbury, na qual um personagem exorta a se agir tal como os atores de um espetáculo, que, após despirem seu figurino, "do alto cume de suas virtudes desprezam o teatro do mundo" (de alto uirtutum culmine theatrum mundi despiciunt). Cf. González-García; Konersmann, op. cit., p. 1051; sobre a presença da obra de Cícero e de Petrônio em Policraticus, cf. Curtius, op. cit., p. 147-48 e nota infra.

${ }^{11}$ Conforme relata a estudiosa, sem a intervenção da audiência e interrupção da atuação, a artista (que, sentada sobre uma superfície de gelo aquecida por uma chama, esvaía-se em sangue) certamente teria desfalecido.
} 
mais exatamente no fato de que, em ambos, focaliza-se a plateia de um teatro (o primeiro, na Atenas pré-cristã, o segundo, na Áustria de algumas décadas atrás) para mostrar audiências em que gestos ou ações dos espectadores passam a equivaler aos de atores.

A escolha desse exemplo específico de perspectiva contemporânea da teatralização da vida deve-se não apenas ao caráter marcante do espetáculo relatado (dirigido a um público não mais acostumado às lutas de gladiadores...), mas também à clareza com que a autora apresenta as premissas modernas de sua abordagem. Em resumo, para tratar do fenômeno da teatralização da vida como objeto da "estética do performativo" que ali se anuncia, E. Fischer-Lichte assume como ponto de partida a terminologia "performative" cunhada na teoria dos "speech-acts" de John L. Austin; ${ }^{12}$ mas, segundo se esclarece, ela a emprega na esteira dos estudos do gênero (nomeadamente da "gender performativity") de Judith Butler, ${ }^{13}$ que extrapola, pois, a esfera da linguagem para tratar do comportamento de um modo mais geral.

O interesse aqui não é empregar tais teorias à análise do diálogo ciceroniano, ${ }^{14}$ nem mesmo comparar mais exaustivamente os sentidos

\footnotetext{
${ }^{12}$ I.e. referente à linguagem que não se limita a descrever uma ação, mas que é parte fundamental para que esta se dê (como a resposta "sim" ao escrivão ou padre na cerimônia de casamento). Pode-se ver, pois, que, para Austin, o termo "performativo", em lugar de denunciar o caráter ilusório da linguagem ou do mundo, serve para enfatizar o potencial constitutivo da linguagem: The name is derived, of course, from "perform", the usual verb with the noun "action": it indicates that the issuing of the utterance is the performing of an action - it is not normally thought of as just saying something (cf. Austin, J. L. How to do things with words. The William James lectures delivered at Harvard University in 1955. Oxford: Clarendon Press, 1962, p. 6).

${ }^{13}$ A identidade, que envolve o gênero (sexual), é, segundo J. Butler, instituída "performativamente" i.e. por meio de uma repetição estilizada de atos (que ela denuncia como geradores, ao invés de resultantes, de tal gênero ou identidade). Cf., por exemplo, Butler,J. Gender trouble. Feminism and the subversion of identity (subversive bodily acts, IV bodily inscriptions, performative subversions). New York: Routledge 1990; idem, Performative acts and gender constitution: an essay in phenomenology and feminist theory. In: Case, S. E. (Org.). Performing feminisms. Feminist critical theory and theatre. Baltimore/ London: Johns Hopkins University Press, 1990, p. 270-282.

${ }^{14} \mathrm{Um}$ exercício de leitura do texto ciceroniano nesse sentido fica, pois, para um outro momento da pesquisa. Para o emprego da teoria de J. Butler nos estudos clássicos, cf., por exemplo, Fuhrer, T.; Zinsli, S. (Org.). Gender studies in den Altertumswissenschaften. Rollenkonstrukte in antiken Texten. Trier: Wissenschaftlicher Verlag Trier 2003; sobre atos de fala em caráter mais geral, cf. Fuhrer, T.; Nelis, D. (ed.). Acting with words. Communication, rhetorical performance and performative acts in Latin literature. Heidelberg: Universitätsverlag Winter, 2010.
} 
da ideia do teatro do mundo que uma e outra obra envolvam. Ao sublinhar a carga conceitual implícita em abordagens recentes, pretendese, em primeiro lugar, chamar atenção para a potencial complexidade de cada instância do tópos também no mundo antigo. Em segundo lugar, o evidenciamento das premissas serve-nos de indício da distância, eventualmente obscurecida pela aparência de familiaridade, entre perspectivas contemporâneas e antigas. Tal distância revelada no contraste se coloca mesmo como condição para se refletir sobre a abordagem do fenômeno antigo, e estímulo para se perguntar pela singularidade do seu emprego e pressupostos em Cícero. Nomeadamente, no que diz respeito ao presente artigo, interessa, pois, perceber o efeito do tópos no diálogo em que talvez seu autor o tenha mais intensamente empregado. Dessa forma, as considerações que aqui expomos têm como objetivo refletir sobre os sentidos e efeitos da teatralização do mundo na obra filosófica em apreço.

Essa, como se sabe, consiste em linhas gerais numa defesa do período da vida humana que atualmente se costuma denominar como "terceira" ou "melhor idade" - o que explica edições modernas adotarem como subtítulo De senectute ("Sobre a velhice"), encontrável (como variante do título) em alguns manuscritos. ${ }^{15} \mathrm{Na}$ obra em estudo, o tópos aparece durante a exposição dos argumentos em prol dessa etapa da vida, expostos em palavras que Cícero atribui ficticiamente ${ }^{16}$ ao personagem epônimo, protagonista do diálogo.

\footnotetext{
${ }^{15}$ Cf. Cícero, op. cit.,1988, p. 93.

${ }^{16} \mathrm{O}$ caráter engendrado da conversa apresentada é assumido pelo autor em seu preâmbulo: por exemplo, quando Cícero afirma que, no diálogo, Catão o Censor seria "mais erudito" (eruditius $\ 3$ ) do que aparentaria nos próprios livros deste. Em meu entender (contrário à leitura de Singh, K. L., op. cit, p. 205), é um reforço à atmosfera de ficção a própria comparação entre o protagonista escolhido e um personagem mitológico, Titono (\$3). As fontes sobre o mito de Titono, homem transformado em cigarra após ter alcançado extrema velhice (por ter obtido de Zeus vida perene, mas não juventude eterna), remontam a Homero, cf. Grimal, P. Dictionnaire de la mythologie grecque et romaine. Paris: PUF, 1963, p. 461; Nünlist, R. Tithonos. In: Cancik, H.; Schneider, H. (Org.). Der Neue Pauly. Stuttgart/Weimar: Metzler, 2002. Vol. XII, p. 627. Sobre uma atmosfera poética derivada já da citação de versos na abertura (caso único nos diálogos), cf. Ruch, M. Le préambule dans les oeuvres philosophiques de Cicéron. Essai sur la genèse de l'art du dialogue. Paris: Les Belles Lettres, 1958, p. 301; Powell, op. cit, 1988, p. 95; e sobretudo Strati, R. Il proemio del "Cato Maior" di Cicerone. Lexis. Trento, vol. XVIII, p. 193-212, 2000.
} 
Tal personagem não é ninguém menos que o então já célebre Marco Pórcio Catão (Marco Porcius Cato), também conhecido como Cato Censor ("Catão o Censor") ou Cato Maior (Catão o Velho), ${ }^{17}$ que havia vivido entre 234 e 149 a.C., portanto cerca de dois séculos antes da composição do diálogo Sobre a velhice. ${ }^{18}$ Retratado à beira dos 84 anos de idade (\$32) e ainda intelectualmente ativo, Catão conversaria (de forma quase monológica, é verdade $)^{19}$ com dois interlocutores jovens à época, os então promissores Gaio Lélio (que seria cônsul dez anos depois, em 140 a.C.) e Cipião Emiliano (cônsul em 147 e em 134 a.C.). ${ }^{20}$

\section{Sobre o estado da questão}

O fato de que o tópos da vida como teatro não tem recebido uma atenção específica nos estudos dedicados à obra ${ }^{21}$ contrasta não apenas com o número de vezes que, conforme referimos, o próprio Cícero ali

\footnotetext{
${ }^{17}$ Como se sabe, a alcunha de Cato Maior ("Catão, o Velho") não denota a idade do referido (coincidentemente apresentado como senex, idoso, na obra em questão: sermonem tribuimus... Marco Catoni seni $\$ 3$; §32; passim); mas visa a distingui-lo de seu bisneto homônimo, cuja alcunha é Cato Minor ("Catão, o Jovem”) ou Catão de Útica (95 a.C.-46a.C.).

${ }^{18} \mathrm{O}$ ano em que Catão completaria 84 anos equivale a 150 a.C., que é, portanto, a data (fictícia) em que se daria a conversa exposta. À época, Gaio Lélio teria 40 anos e Cipião Emiliano, 35. Cf. Singh. op. cit., p. 353.

${ }^{19} \mathrm{O}$ caráter de solilóquio predominante em Cato Maior de senectute (bem como em De amicitia e em cada livro das obras Academica, De Finibus, De natura deorum e De dininatione) não destoa das convenções do gênero dialógico, ao menos das presentes nos diálogos platônicos mais lidos em Roma da época de Cícero, cf. Boyancé, P. Le Platonisme à Rome: Platon et Cicéron. In: Actes du Congrès del'Association G. Budé (Tours et Poitiers, 1953). Paris: Les Belles Lettres, 1954, p. 195-222; Cícero, op. cit., 1988, p. 5-6.

${ }^{20}$ Cf. Singh, op. cit., p. 205; 353-54, n. 4; Cícero, op. cit., 1988, p. 102.

${ }^{21}$ É preciso dizer que tampouco nas pesquisas sobre a história do tópos do theatrum mundi a obra de Marco Túlio Cícero tem recebido a devida consideração. Veja-se, por exemplo, a lacuna no verbete respectivo no monumental dicionário Ritter (cf. González-García; Konersmann, op. cit.), em que, ao se tratar da ideia entre os autores em Roma, passa-se diretamente a Sêneca; no capítulo que E. R. Curtius (op. cit.) dedica à "metáfora do ator" (Schauspielmetapher), há breve menção a Cato Maior \$65 (como paralelo para Sêneca e Boécio, cf. Curtius, op. cit., p.146) e uma sugestão da presença de um episódio ciceroniano (o “Sonho de Cipião”, De Republica VI, 10ss.) na obra em que J. de Salisbury cunha a expressão theatrum mundi (cf. nota acima). O
} 
o emprega, mas também com o fato de que Cato Maior tem sido (e provavelmente ainda hoje é) um dos textos ciceronianos mais editados. ${ }^{22}$

A atenção ao diálogo tem-se voltado notoriamente à edição crítica do texto, ${ }^{23}$ à pesquisa das fontes ciceronianas ${ }^{24} \mathrm{e}$, sobretudo, à historicidade ou não quer da imagem de Catão o Velho oferecida por Cícero, ${ }^{25}$ quer das anedotas contadas pelo personagem. ${ }^{26}$ Menos frequentes são as contribuições que destacam aspectos retóricos (estilísticos e argumentativos), tanto em passagens isoladas, ${ }^{27}$ quanto

theatrum mundi de Cícero tem um pouco mais de espaço em Kokolakis, op. cit., p. 2831 (mas ali apenas se elencam e comentam brevemente as passagens) e em Christian, L. G. Theatrum mundi. The history of an idea. New York: Garland, 1987 (que desenvolve mais o tópico, mas numa direção que interessa mais à história da ideia do que ao seu efeito nas obras de nosso autor).

${ }^{22}$ Aucun ouvrage de Cicéron a été aussi souvent édité, afirma P. Wuilleumier em introdução à sua própria edição da obra (Cicero. Caton l'ancien (de la vieillesse). Texte établi et traduit par Pierre Wuilleumier. Paris: Les Belles Lettres, 1961, p. 70). No Brasil, o interesse editorial se reflete, basicamente, na divulgação da tradução da obra, como por exemplo, a versão de P. Neves (Cícero. "Saber envelhecer" seguido de "Amizade". Porto Alegre: L\&PM Pocket, 1997); ou a de M. Kury (Cícero. Cato Maior de senectute. Catão, o Velho ou Diálogo sobre a velhice. Porto Alegre: EDIPUCRS, 1998).

${ }^{23}$ Por exemplo, Prima, A. Cicerone, "Cato Maior" 48 e 53. Paideia. v. XIII, p. 247-251, 1958; Fraenkel, E. Tulliana. Mus. Helv Basel, vol. XXIII, p. 194, 1966 (contra, Cícero, op. cit., 1988, p. 108).

${ }^{24}$ Entre outros, vejam-se: Alfonsi, L. Sulle fonti del "De senectute". La Parola del passato. Napoli, v. XLI, p. 121-129, 1955; Manfredini, M. Argantonio re di Cadice e le fonti del "Cato Maior" ciceroniano. RFIC. Torino, vol. XCVIII, p. 278-291, 1970; Castelli, G. "Cato maior de senectute" come Herakleideion. RSC. Torino, vol. XX, 1972, p. 5-12.

${ }^{25}$ Remeto, por exemplo, à bibliografia elencada em "The 'Cato' as a historical source", terceiro apêndice de Cícero, op. cit, 1988, p. 273-79.

${ }^{26}$ Cf. Tornos, A. M. La historia en el diálogo "De senectute". Humanidades. vol. V, p. 272-280, 1953; Venini, P. La vecchiaia nel "De senectute" di Cicerone. Athenaeum. Pavia, vol. XXXVIII, p. 98-117, 1960; Feig Vishnia, R. Cicero. "De senectute" 11, and the date of C. Flaminius' tribunate. Phoenix. Toronto, vol. L, n. 2, p. 138-145, 1996; cf. ainda Cícero, op. cit, 1988, p. 273-279.

${ }^{27}$ Sobre o excurso acerca da vida no campo (\$51-61), cf. Novara, A. Le vieux Caton aux champs ou le plaisir exceptionnel de l'agriculture pour un sage vieillard. In: Le Bonniec, H.; Vallet, G. Mélanges P. Wuilleumier. Paris: Les Belles Lettres, 1980, p. 26168. Sobre o cuidado com que Cícero introduz citações de Ênio e outros arcaísmos no prólogo, cf. Strati, op. cit. 
no diálogo como um todo. ${ }^{28}$ Nesse sentido, é excepcional a edição comentada que Powell em 1988 publica em Cambridge. Nela se destaca a introdução, que aprecia a presença e efeitos da articulação entre retórica e filosofia ${ }^{29}$ no texto ciceroniano, atentando, inclusive, para convenções específicas do diálogo filosófico antigo.

Contudo, como pretendo ressaltar, as cinco passagens mais explícitas do theatrum mundi neste diálogo ainda não foram, nem mesmo por Powell, consideradas nesta perspectiva. No comentário à imagem teatral a cada uma delas, o estudioso recorda (sem ser exaustivo) a presença da ideia noutras obras de Cícero e associa diretamente o emprego do tópos à modernamente chamada "filosofia popular" antiga. ${ }^{30}$ Apesar disso, como veremos, ao deixar perceber em seus comentários a presença do teatro como panorama de fundo à obra em apreço, Powell nos auxilia a nela entrever um emprego mais consistente e influente do tópos que apresenta a vida como um espetáculo.

\footnotetext{
${ }^{28}$ A coerência no diálogo Cato Maior é valorizada por Alfonsi, L. La composizione del "De senectute" ciceroniano. Siculorum Gymnasium. Catania, vol. VIII, p. 429-454, 1955 (1961); uma apreciação do uso de citações nas obras filosóficas de Cícero em geral, incluindo Cato Maior, pode ser encontrada em Spahlinger, L. Tulliana simplicitas. $Z u$ Form und Funktion des Zitats in den philosophischen Dialogen Ciceros. Göttingen: Vandenhoeck und Ruprecht, 2005.

${ }^{29}$ No tocante à relação entre retórica e filosofia em Cícero, ver também a útil introdução do estudioso a Powell, J. G. F. (Org.). Cicero the philosopher. Twelve papers. Oxford: Clarendon Press, 1995, p. 1-35. Uma imagem do versátil Cícero enquanto predominantemente filósofo é defendida por W. Stroh (Cicero, Redner, Staatsmann, Philosoph. München: Beck, 2008).

${ }^{30}$ Powell (Cícero, op. cit., 1988, p. 109) é, no entanto, cauteloso ao ponderar que a presença do tópos nas passagens específicas, ou mesmo em Cato Maior em geral (cf. op. cit, 1988, p. 13), não é conclusiva para uma determinação das fontes filosóficas de Cícero nesta obra. Outra é, como veremos, a posição de Léfevre, E. (Der "Tithonos" Aristons von Chios und Ciceros "Cato". Hermes. Stuttgart, vol. CXXXV, p. 43-65, 2007), que associa o tópos ao estoicismo. Sobre a tradição da moderna chamada "filosofia popular" ou "diatribe" helenística e romana, cf. Powell (Cícero, op. cit., 1988, p. 13), que refuta o ponto de vista de que teria havido uma extrema influência desse tipo de filosofia em Cato Maior, asseverado por P. Wuilleumier (op. cit.). Sobre a diatribe, a obra de referência é Oltramare, A. Les origines de la diatribe romaine. Genebra: Payot, 1926; cf. ainda Jocelyn, H. D. Diatribes and sermons. Liverpool Classical Monthly. Liverpool, vol. VII, p. 3-7, 1982. Sobre a origem do termo "diatribe" e de sua aplicação moderna, cf. Görgemanns, H.; Uthemann, K.-H. Diatribe. In: Cancik; Schneider, op. cit., vol. III, 1997, p. 530-533; Goulet-Cazé, M.O. Popularphilosophie. In: ibidem, vol. X, 2001, p. 154-155.
} 


\section{A natureza como poeta dramático (§5)}

A primeira das cinco passagens normalmente reconhecidas como ocorrência do tópos do theatrum mundi em Cato Maior faz parte da fala inicial de Catão. Com ela, o octogenário responde a um comentário elogioso de um dos seus jovens interlocutores. Contestando a surpresa quanto ao fato de que, naquela idade, levasse a vida de modo excelente (excellentem \$4) e em tão plena sabedoria (perfectam sapientiam \$4), ele diz:

Quodcirca si sapientiam meam admirari soletis (quae utinam digna esset opinione uestra nostroque cognomine!), in hoc sumus sapientes, quod naturam, optimam ducem, tamquam deum sequimur eique paremus; a qua non ueri simile est, cum ceterae partes aetatis bene descriptae sint, extremum actum tamquam ab inerti poeta esse negletum $\left(\$ 5\right.$, grifos meus). ${ }^{31}$

Aqui, ao se apresentar a velhice como o ato final (extremum actum) de um drama, a vida humana é retratada como um espetáculo que seguiria o roteiro elaborado pela natureza. Esta é, como se nota, personificada como poeta: não um negligente em sua arte, mas atento a todas as partes do drama da vida (partes aetatis). Nesta primeira apreciação, já podemos constatar que, no trecho que acabamos de ler, tem-se uma imagem positiva, tanto da vida, quanto do teatro: ao elogiar a eficiência do compositor do espetáculo, o personagem não exorta a um desprezo pelo roteiro mundano, ${ }^{32}$ nem usa a ideia para descrever pejorativamente a velhice. ${ }^{33}$

Numa breve comparação com outros registros antigos do tópos, é digno de nota que a menção à natureza distingue essa passagem de alguns de seus notórios paralelos na filosofia helenística. Por exemplo,

\footnotetext{
${ }^{31}$ Cícero, Cato Maior 5: "Pois, se vocês costumam admirar minha sabedoria (quem dera ela fosse digna de sua opinião e de meu cognome!), somos sábios nisto: pelo fato de que seguimos a natureza, a melhor líder, como a um deus, e a ela obedecemos. Pois não é verossímil que, tendo ela composto bem as demais partes do drama da vida, o ato final seja negligenciado, tal qual por um poeta inepto".

${ }^{32}$ Diferentemente, pois, do sentido da formulação em Policrático, vide nota supra.

${ }^{33}$ Como se pode ler - mas não sem ironia, como gentilmente recorda Erick Ramalho de S. Lima (Centro de Estudos Shakespeareanos/ Belo Horizonte) em palestra na FALE-UFMG - na expressão do melancólico personagem Jacques, da comédia $A s$ you like it (cf. nota supra): Last scene of all, that ends this strange eventful history, is second childishness and mere oblivion; sans teeth, sans eyes, sans taste, sans everything (ato II, cena VII, versos 163-166).
} 
já se apontou a passagem do filósofo Bíon de Borístenes (c. 335- c. 245 a. C) ${ }^{34}$ na qual o espetáculo em que o ser humano atuaria seria dirigido por um deus (hò theós), ou, ainda, pela Fortuna (túkhe).

Ora, estaria a ênfase no papel da natureza associada também às demais ocorrências do "teatro do mundo" em Cato Maior? Ou, antes disso, haveria uma unidade, ou mesmo uma relação coerente entre tais passagens? Para responder a essa questão, é preciso investigar, primeiramente, em que sentido a vida equivale a teatro nos demais passos do diálogo ciceroniano e, a seguir, que função essa metáfora nele desempenharia.

\section{Partes aetatis ( $\S 5$ ): fases, atos ou papéis?}

Ao traduzir por "partes do drama da vida" a expressão partes aetatis, visa-se ressaltar a polissemia da expressão latina no contexto da passagem acima transcrita. Com isso, a leitura aqui proposta se assemelha à de tradutores que buscaram recuperar o duplo sentido do termo, ${ }^{35}$ mantendo significados que certos estudiosos chegaram a considerar excludentes, a saber: de um lado, o de "parte da vida", ou seja, "fase da vida", "idade", e, de outro, uma nuança teatral (por exemplo, "parte de uma peça"). Ora, é verdade que o primeiro sentido é consistente, não apenas com o tema do parágrafo 5 , como também, conforme lembra Powell, com a dicção do personagem ciceroniano em outras passagens. ${ }^{37} \mathrm{O}$ segundo

\footnotetext{
${ }^{34}$ Frg. 16 = Teles, Perí autarkeías, apud Estobeu, Florilegium 3.1.98 (= fr. II, p. 5.2-6-8 Hense). Cf. Kindstrand, J. F. Bion of Borysthenes. Stockholm: Almqvist Wiksell, 1976, p. 116-17, 204-12; Powell op. cit., 1999, p. 108.

${ }^{35}$ Como, por exemplo, the other acts of life's drama (Falconer, W. A. In: Cicero. De senectute; De amicitia; De diuinatione. London/ Cambridge, Mass.: Harvard University Press, 1971, p. 12); le altre parte del drama della vita... (Cicerone. La vecchiezza; L'amicizia. A cura di G. Pacitti. Verona: Arnoldo Mondatori, 1965, p. 34); alle anderen "Akte" des Lebens (Cicero. Cato Maior de senectute. Edição por M. Faltner. München: Heimeran Verlag, 1963, p. 11-12). Nas traduções para o português consultadas, a ambiguidade não foi ressaltada, cf. M. Kury (op. cit.) e P. Novaes (op. cit.), respectivamente: as outras etapas da vida, os outros períodos da vida.

${ }^{36}$ É tendo em vista privilegiar no vocábulo partes o sentido de parte (em grego, mére) num drama que Fraenkel (op. cit., p. 194) chega a propor que o termo aetatis seria interpolação. Agradeço a David Konstan (New York University) a discussão sobre a passagem.

${ }^{37}$ Cf. Powell (Cícero, op. cit, 1988, p. 108), que remete a Cato Maior \parti aetatis 33; omnis aetas $\$ 4,7 \mathrm{e} 9$.
} 
sentido da expressão partis aetatis faz parte, a meu ver, do emprego do tópos do theatrum mundi no mesmo parágrafo. $\mathrm{Na}$ seção seguinte, esclareço que esse ponto de vista, apesar de divergir da leitura do estudioso quanto ao termo específico, apoia-se em seu erudito comentário a várias passagens do diálogo. ${ }^{38}$

Reforça a hipótese da polissemia em partes aetatis a percepção de que uma atmosfera teatral - propícia à equivalência entre partes e atos (ou papéis) de uma peça, natureza e dramaturgo, em suma, entre vida e teatro - já se vinha anunciando antes da primeira formulação do tópos do theatrum mundi no mesmo texto.

Por exemplo, na primeira fala de Lélio, um dos jovens interlocutores de Catão no diálogo, compara-se o fardo (onus §4) da velhice com o peso do Etna: "Pois ela é a muitos velhos tão odiosa, que eles chegam a dizer que carregam um fardo mais pesado que o próprio Etna" (Quae plerisque senibus sic odiosa est ut onus se Aetna grauius dicant sustinere \$4).

É bem possível que, como sugere Powell, a referência remonte a uma passagem do coro da tragédia euripidiana Hércules Furioso (v. 637), em que, num contexto de reclamação sobre a velhice, se menciona a prisão dos gigantes rebeldes sob o referido monte. Como o estudioso recorda, embora o mito tivesse sido retomado pelo poeta alexandrino Calímaco (Aetia, fr. 1) e por Teles (p. 42; 51 H.), "presumably Cicero was quite able to recall Euripides directly" . Cabe dizer o mesmo do público desse diálogo ciceroniano, se tomarmos por base aquele a quem

\footnotetext{
${ }^{38}$ A explícita intenção de evitar certa nuança teatral em partes (a de dramatis persona, isto é, de "papéis numa peça ou num drama") evidencia o fato de que, na sua consideração da obra, Powell (Cícero, op. cit., 1988, p. 108) não concede uma maior abrangência ao tópos do theatrum mundi, cuja presença ele reconhecerá apenas mais adiante no mesmo parágrafo, a saber, à altura de extremum actum (designando, como vimos, "ato final" de uma peça) e em poeta (na acepção de "dramaturgo"). É curioso que em nenhuma das traduções consultadas se note em partes aetatis o sentido de "papéis da vida" que Powell pretende contornar (significado que é, no entanto, abalizado pelo $O L D$ e pelo $T h L L)$.

${ }^{39}$ Cf. Cícero, op. cit., 1988, p. 104. Para exemplos do modo como Cícero recorre a tragédias de Eurípides em contextos de denúncia de atitudes tirânicas, cf. Pianezzola, E. Politica e poesia in Cicerone, "Le Fenicie" di Euripide. Ciceroniana. Roma, vol. V, p. 167-172, 1984; de modo mais geral, cf. entre outros, Goldberg, S. Cicero and the work of tragedy. In: Manuwald, G. (Org.). Identität und Alterität in der frührömischen Tragödie. Würzburg: Ergon-Verlag, 2000, p. 49-59; Eigler, U. Cicero und die römische Tragödie. In: Stärk, E.; Vogt-Spira, G. (Org.). Dramatische Wäldchen. Festschrift für Eckard Lefevvre. Zürich/ New York: Olms, p. 619-636.
} 
é dedicado, o cavaleiro romano Tito Pompônio Ático, notoriamente interessado pela cultura greco-romana em geral (Cato Maior, $\$ \$ 1-3){ }^{40}$

No final da fala em que se introduz o tópos do theatrum mundi, o mesmo mito dos gigantes rebeldes é retomado quando Catão pergunta: Quid est enim aliud Gigantum modum bellare cum dis, nisi naturae repugnare (Cato Maior 5 "Pois o que é guerrear contra os deuses, ao modo dos gigantes, a não ser lutar contra a natureza?")? Emprega-se aqui a referência ao combate dos gigantes no sentido de empenhar-se sem perspectiva de sucesso. O curioso é que, ao que parece, a menção do mesmo episódio mitológico nessa conotação precisa é registrada antes de Cícero apenas no texto de uma comédia de Plauto: Disne aduorser quasi Titani ("Vou combater os deuses, como os titãs?", Persa 26-7) ? ${ }^{41}$ Dessa forma, seguindo os paralelos apontados por Powell, podemos pensar que Catão estaria aqui retrucando, num tom cômico e bem-humorado, a alusão euripidiana implícita na fala com que seu interlocutor denotara o exagero no peso da velhice alegado pela maioria dos velhos.

Evidentemente, apenas a ideia de que as referidas menções a gigantes e Etna pudessem ser reconhecidas pelo público ciceroniano como referência ao gênero dramático não as transforma em uma ocorrência de theatrum mundi. Mas, se efetiva, a alusão reforça a possibilidade de que, para o leitor de Cícero, uma equivalência entre vida e teatro seja paulatinamente preparada e mais facilmente reconhecível à altura em que se enuncia partes aetatis.

Se, porventura, não aceitamos a validade do caráter alusivo, a estratégia de ponderar quanto à sutil insinuação do teatro nas referidas falas vem, ao menos, chamar a atenção para o fato de que, no prosseguir do texto, o diálogo Cato Maior será efetivamente pontuado por menções explícitas a dramaturgos e suas peças, personagens e atores do palco cênico grego e romano. ${ }^{42}$

\footnotetext{
${ }^{40}$ Att. 15. 27. 2; 16.2.6.4; 16.6.4. Ático é destinatário de três diálogos filosóficos de Cícero: além de Cato Maior, há o diálogo Sobre a amizade (Laelius de amicitia) e o (perdido) Degloria (cf. Ruch, op. cit., p. 300); Cícero, op. cit., 1988, p. 2-3.

${ }^{41}$ O mito tem outros usos alegóricos em Cícero (Har. resp. 20), Horácio (Od. 3.4) e Plutarco (De facie 926d-e), segundo Powell (Cícero, op. cit., 1988, p. 110).

${ }^{42}$ Entre as referências, menciona-se o dramaturgo Sófocles (Cato Maior 47) e seu Édipo em Colono (22); de Cecílio Estácio, citam-se trechos de suas comédias (\$2429) e ainda personagens típicos (comicos stultos senes, 36); evocam-se ainda: o teatro de Dioniso na Grécia; o ator romano Turpião Ambívio (48); o comediógrafo Plauto (50), entre outros. Apresento, de forma resumida, as passagens em que se podem perceber referências a teatro, assinalando com interrogação as possíveis alusões
} 


\section{O ser humano como espectador (\$48)}

Para viver bem a velhice, este último ato da vida, basta, pois, segundo Catão, seguir o roteiro da natureza ( $(5)$. Na defesa desta ideia, o personagem se propõe a refutar as objeções que normalmente se apresentariam contra ela. É, pois, em forma de contra-argumentação que ele constitui sua partitio, o plano de sua exposição (\$ 15). A próxima ocorrência do tópos do theatrum mundi vai-se dar 43 parágrafos após a primeira, em uma discussão acerca da terceira crítica a ser refutada contra a velhice: ${ }^{43}$ a queixa acerca da diminuição dos prazeres.

O tratamento dessa crítica à velhice começa um pouco antes disso (\$39). Após condenar os prazeres (uoluptates), sobretudo os sexuais, Catão refuta a ideia de que toda espécie de deleite se extinga por completo na velhice. ${ }^{44}$ Uma idade avançada requereria apenas a moderação (cf. modice, mitiora $\$ 45$ ) de certos tipos de prazer (por meio do equilíbrio nas refeições, por exemplo) e o privilégio de outros que não os corporais (em detrimento dos alimentos, os da convivência, mais apropriada aos banquetes, conuiuia $(\$ 45)$. Nesse contexto apresenta-se a ideia de que a velhice traria inclusive uma vantagem: favorecer a escolha dos melhores prazeres. $\mathrm{O}$ argumento é reforçado por uma anedota, importada das Leis de Platão (Nómoi 329b), acerca da excessiva libido (rebus ueneriis \$47) de Sófocles quando jovem. Imediatamente após a história picante sobre o dramaturgo grego, vem mais uma referência ao teatro, que servirá como ênfase ao fato de que grandes prazeres permanecem na velhice:

(essas, apontadas por Powell em Cícero, op. cit, 1988, ad loc): \ 4 (?); \$5 (?); \$20; \22

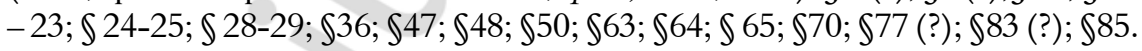
Cf. ainda Zillinger, W. Cicero und die altrömischer Dichter. Würzburg: Staudenraus, 1911, p. 175-76.

${ }^{43}$ As demais queixas a serem refutadas são $(\$ 15)$ : a de que a velhice afastaria o homem de suas atividades; a de que enfraqueceria o corpo; e, em quarto e último lugar, a proximidade entre a idade avançada e a morte.

${ }^{44}$ Com razão afirma Powell (Cícero, op. cit., 1988, p. 181): There is no logical inconsistence between the two halves of the argument, as different sorts of pleasure are in question. Outro fator que favorece a consistência lógica da argumentação de Catão quanto aos prazeres na velhice é, no meu entender, a construção do discurso: o fato de que o primeiro argumento (i.e. a refutação de todos os prazeres como "a peste mais fatal... lançada pela natureza”, capitaliorem peste... a natura datam $\$ 39)$ coloca-se no discurso de outra pessoa (tradita est \$39), a saber, de um certo Árquitas de Tarento. O segundo argumento, que defende a seleção dos prazeres precisamente pelo seu caráter natural (\$46), é defendido mais diretamente por Catão. 
Quod si istis ipsis uoluptatibus bona aetas fruitur libentius, primum paruulis fruitur rebus ut diximus, deinde eis quibus senectus etiamsi non abunde potitur, non omino caret: ut Turpione Ambiuio magis delectatur qui in prima cauea spectat, delectatur tamen etiam qui in ultima, sic adulescentia uoluptates propter intuens magis fortasse laetatur, sed delectatur etiam senectus procul eas spectans tantum quantum sat est ( $\$ 48$, grifos meus). ${ }^{45}$

A menção a Turpião Ambívio, ${ }^{46}$ ator admirado na época de Catão, e à cauea ("auditório") servem, em primeiro lugar (da mesma forma que a referência a Sófocles na anedota que acabamos de mencionar), como parte da argumentação indutiva: desta vez, como exemplo dos prazeres da vida. Mas, de modo análogo à maneira como Catão vinhase referindo figurativa e denotativamente a banquetes $(\$ 44),{ }^{47}$ o espaço teatral será utilizado, de súbito, também em outros sentidos figurativos: por meio das conjunções ut... sic... ("tanto... quanto..."), Turpião Ambívio será transformado, metonimicamente, em teatro, e, ao mesmo tempo, metaforicamente, em vida teatralizada. Assim, a velhice passa a equivaler não mais à última atuação (extremum actum $\$ 5$ ), mas sim a um sentar-se confortavelmente na última fileira de um teatro.

\footnotetext{
${ }^{45}$ Cícero, Cato Maior 48: "Pois, se desse tipo de prazer a 'boa idade' [leia-se, a juventude] usufrui de mais bom grado, em primeiro lugar, ela usufrui, como já dissemos, de coisas mesquinhas; além disso, mesmo que a velhice não possa fazer uso dos prazeres em abundância, deles ela não se priva completamente: alguém que se encontre na primeira parte da plateia se deleita mais com Turpião Ambívio; no entanto, deleita-se também quem que se encontra na última parte. Da mesma forma, a juventude, assistindo aos prazeres de perto, talvez se alegre; mas também a velhice, como um espectador à distância, deleita-se tanto quanto lhe basta".

${ }^{46}$ De Ambívio Turpião, empresário, diretor e ator à época de Catão, sabe-se que teria atuado com sucesso, por exemplo, em comédias de Terêncio: em Formião (cf. comentário de Donato a Ter. Phorm. 315); no prólogo de O Autoflagelador (Heautontimorumenos) e em A Sogra (Hecyra), cf. ainda Tácito, Dial. 20; Beare, W. The Roman stage. London: Methuen, 1955; Blume, H.-D. Ambivius Turpio. In: Cancik; Schneider, op. cit., vol. I, 1996, p. 580; Cícero, op. cit., 1988, p. 200.

${ }^{47}$ Os banquetes (designados por epulae e conuiuia) são mencionados pelo protagonista ora denotativamente (como mero exemplo de prazeres), ora de modo figurativo (na função de símbolo de todos os prazeres). Este sentido fica mais claro na designação das uoluptates por meio de uma formulação platônica (cf. Timeu 69d) "isca dos males" (em latim escam malorum \$44); e é ainda desenvolvido em construções singulares (como a hipálage em pocula rorantia, lit. "taças orvalhantes" \$46), com que Catão se refere ao Banquete de Xenofante. Cf. discussão em Cícero, op. cit., 1988, p. 196.
} 
Salta aos olhos que a comparação da vida com o teatro sofre, portanto, uma importante modificação: o homem é apresentado não mais como um ator da peça escrita pela natureza $(\$ 5)$, mas sim como um espectador dos prazeres da vida. Para Powell a imagem nesse parágrafo é singular, não apenas no que diz respeito à tradição de theatrum mundi a que Cícero teria acesso, ${ }^{48}$ como também no tocante ao diálogo em que aparece. Neste sentido, o estudioso prefere não a classificar junto com as demais passagens de Cato Maior em que a vida é comparada a teatro, visto que aqui a comparação seria "nada mais do que a ilustração de um ponto particular". ${ }^{49}$

\section{O ser humano como ator (\$ 64)}

Ora, é verdade que somente vinte e dois parágrafos depois da menção a Turpião Ambívio volta-se à metáfora do teatro do mundo. Além de haver, de novo, um grande intervalo entre as ocorrências do tópos, agora o ser humano é caracterizado de modo explícito, tal como pressuposto no parágrafo 5, como um ator (o termo usado será histrio) do espetáculo da vida. O contexto é ainda o da discussão quanto aos prazeres do idoso:

Quae sunt igitur uoluptates corporis cum auctoritatis praemiis comparandae? Quibus qui splendide usi sunt, ei mihi uidenturfabulam aetatis peregisse ${ }^{50}$ nec tamquam inexercitati histriones in extremo_actu corruisse ( $\$ 64$, grifos meus).$^{51}$

\footnotetext{
${ }^{48}$ Cf. Cícero, op. cit., 1988, p. 200: There is no striking parallel to this in the Greek popular philosophical tradition, and it is an entirely Roman example.

${ }^{49}$ Cito de forma mais completa: Again Cicero draws his comparisons from the stage (...) here however there is no more than a simple illustration of a single point, and it is inapropriate to classify this together with the more extensive theatrical imagery of $₫ 5,64,70,85$.

${ }^{50}$ Peregisse: a tradução no corpo do texto segue o sentido 4 previsto ao verbo perago no $O L D$, frequentement tendo como objeto partes: "to play a role" (tal qual o verbo $a g o$ ), mas enfatizando a ideia de completude, sucesso no desempenho do papel (cf. perago, OLD, sentido 5). No entanto, o contexto estimula a se perceber o jogo com os sentidos de vida e teatro, nomeadamente, a presença do sentido: "to live out (a period of time)", mais precisamente $10 \mathrm{~b}$ "to come to end of, complete (a period of time)"; "ter alcançado o final da vida" (item 10, OLD).

${ }^{51}$ Cícero, Cato Maior 5: "O que são, portanto, os prazeres do corpo, quando comparados às recompensas da autoridade? Os homens que delas fizeram uso com elegância parecem-me ter desempenhado com perfeição a peça da vida, ao invés de terem desabado no ato final, tais quais atores sem preparo".
} 
No entanto, apesar da diferença nas imagens de homem (ora como ator, ora como espectador) e da distância entre as passagens de theatrum mundi até aqui apreciadas, parece-me que uma relação mais forte e significativa existe entre elas.

Um primeiro indício de tal integração é a constatação, acima mencionada ${ }^{52}$ de tantas referências a teatro na obra em estudo. Porém, muitas das referências ao teatro privilegiadas nesta observação de Cato Maior fazem parte de conjunto mais amplo e variado de outros exemplos nos quais o discurso do personagem Catão é baseado, muitos deles apresentados como derivados de uma experiência pessoal do personagem. Essa argumentação indutiva - que combina não apenas com a composição do caráter de um velho, como também com a recepção romana do tipo de sapientia prática propagada nos escritos e atos do Catão que vivera séculos atrás $^{53}$ - inclui tantas outras referências (a poetas em geral, a filósofos e personagens históricos), ${ }^{54}$ que é de se pensar se acaso, apesar de numerosas, as menções a atores, dramaturgos e peças não seriam de certa forma obscurecidas numa leitura menos direcionada do que a aqui proposta.

Contudo, não é apenas uma questão de quantidade: também o modo como as referências ao mundo cênico (evidentes ou aludidas, espalhadas pelo texto) são inseridas nesse diálogo filosófico precisa ser levado em conta antes de se admitir a associação entre as ocorrências do tópos e aquelas. No próximo item, pretende-se demonstrar que mesmo referências ao mundo cênico que não explicitam tão claramente a equivalência do teatro do mundo contribuem para que atmosfera teatral se mantenha de modo privilegiado nessa obra em que a metáfora é explícita tantas vezes, apesar da distância e de certa variedade. ${ }^{55}$

\footnotetext{
${ }^{52}$ Cf. enumeração das passagens em nota supra.

${ }^{53}$ Cf. por exemplo, as advertências de Catão a seu filho, conforme transmitido por Plínio o Velho (Nat. Hist. 29, 14). Sobre a paradoxal relação de Catão com os gregos, cf. por exemplo, Astin, A. E. Cato and the Greeks. In: . Cato the Censor. Oxford: Clarendon Press, 1978, p. 157-181. Sobre uma articulação entre o sophós estoico e sapiens (cognome de Catão) na primeira enunciação do theatrum mundi (\$5), ver ainda Lefevre, op. cit., p. 48-49 e 61. Um interessante contraste entre sapientia (romana) e philosophía (grega) associado ao personagem histórico Catão é proposto na leitura do prefácio a Tusculanae I, \$1-2 por Gildenhard, I. Paideia Romana. Cambridge: University Press, 2007, p. 110; 114-116.

${ }^{54}$ Sobre os exempla históricos, cf. Cícero, op. cit., 1988, p. 9-10.

${ }^{55}$ Alguns dos elementos cênicos citados em Cato Maior, como versos de Cecílio Estácio e Terêncio, aparecem em discursos jurídicos ciceronianos compostos previamente, e com tal ênfase que, embora não se costume reconhecer a existência
} 


\section{O ser humano como espectador/ ator (§§ 63-64, § 70)}

Voltemos um pouco na leitura, a fim de apreciar, pois, a forma como a terceira passagem da vida teatralizada se anunciava. Ao final de uma longa digressão sobre a vida no campo (\$51-61), o personagem Catão sublinha, por meio de uma metáfora singular à época de Cícero, a autoridade como sendo a mais alta distinção $(\text { apex })^{56}$ da velhice. A ideia será desenvolvida por meio da anedota do ancião no teatro de Dioniso, a qual introduz o presente estudo (\$63-64).

Na história contada por Catão, como vimos, não foi o ato de atores sobre o palco que a plateia restante aplaudiu, mas a conduta dos embaixadores espartanos, que eram, como os demais, espectadores; e, consecutivamente, o aplauso (mais um ato da plateia) também foi objeto de juízo, manifesto por um dos espectadores.

Ora, a anedota se situa imediatamente antes da já mencionada passagem em que o homem é comparado a um ator (\$64). Ela permite, assim, observar nova transformação da metáfora: o ator (implícito no $\$ 5)$ se tornara espectador (no $\ 48$ ). Agora, por meio da anedota (\$63), o ambiente do auditório é ainda focalizado, mas Catão introduz algo novo: espectadores (no caso, os espartanos e o velho) mostram-se ao mesmo tempo também atores, que - de modo supostamente diverso dos atenienses - desempenhariam bem o seu papel. Moral da história: o papel do homem é viver sua vida de modo eticamente correto, i.e. usufruindo dos prazeres da vida com o discernimento de um espectador

do tópos do teatro do mundo na oratória ciceroniana, desenvolvo, na atual pesquisa sobre o corpus, a hipótese de que a ideia da vida como teatro é efetivamente premissa para determinadas passagens da argumentação jurídica, nomeadamente de discursos como Em defesa de Célio (Pro Caelio), Em defesa de Róscio, o Comediante (Pro Roscio Comoedo), Em defesa de Séstio (Pro Sestio). Cf., de forma resumida, Cardoso I. T. "Theatrum mundi" na oratória de Cícero. Anales del IV Coloquio Internacional: lenguaje, discurso y civilización de Grecia a la modernidad. La Plata: 2006. Vol. I, p. 32; idem, "Theatrum mundi": Leben als Nachahmung des Theaters in Ciceros Redekunst. Von Humboldt's introdutory meeting. Leipzig/ Bonn: Von Humboldt, 2006, p. 10; idem, "Theatrum mundi": Philologie und Nachahmung. In: Schwindt, J. P. (Org.). Was ist eine Philologische Frage? Frankfurt am Main: Suhrkamp, 2009, p. 82-111.

${ }^{56}$ Apex est autem senectutis auctoritas ( $\left.\$ 61\right)$. Sobre a novidade no uso de apex com esse sentido, cf. a assertiva de Powell em Cícero, op. cit., 1988, p. 231: The Roman "apex" was originally an olive-twig tied round with woll, placed in the cap offlamines; a metáfora continuou singular, o passo é the only instance of this metaphor in classical Latin, discounting imitations of this passage. 
distanciado, de modo que ao fim possa desempenhar, com a devida autoridade (\$61) e experiência que o impeça de desabar (\$64), o papel de ancião honrado (\$64).

Em outras palavras, admitir a associação entre essa referência a teatro e os enunciados de theatrum mundi implica, pois, a possibilidade de uma relação entre os passos $\$ 5, \$ 48, \$ 64$. Nesse sentido também colabora a próxima passagem de theatrum mundi, que ocorrerá durante a investigação da proximidade da morte (a última queixa elencada contra a velhice) e repete a imagem do homem como ator:

Quod cuique temporis ad uiuendum datur, eo debet esse contentus. Neque enim histrioni ut placeat peragenda fabula est, modo in quocumque fuerit actu probetur, neque sapienti usque ad "plaudite”, ueniendum est; breue enim tempus aetatis satis longum est ad bene honesteque uiuendum (\$69-70, grifos meus). ${ }^{57}$

Interessa a nossas considerações da integração entre as passagens da vida como teatro, sobretudo, o modo como se usa aqui a referência a aplausos (em plaudite, "aplaudam"), sinalizando o pedido de aplausos pertinente à finalização de uma apresentação teatral. ${ }^{58} \mathrm{~A}$ referência a tal convenção cênica ajuda a perceber a cauea ("auditório") do teatro de Dioniso já como um palco e, portanto, o valor dessa passagem na articulação entre as ocorrências de theatrum mundi apreciadas até o momento. ${ }^{59}$

Essa, por sua vez, deixa notar que a ordem com que cada um dos referidos passos se apresenta no texto não é casual. Passemos, pois, ao último deles, que se dá no parágrafo final do diálogo.

\footnotetext{
${ }^{57}$ Cícero, Cato Maior 69-70: "Cada um deve se contentar com (qualquer que seja) o tempo de viver que lhe foi concedido. Pois, para agradar, um ator não precisa atuar na peça até o final, contanto que seja aprovado em qualquer ato que estiver presente. Da mesma forma, o sábio não precisa chegar até o aplaudam; pois um breve tempo de vida é longo o suficiente para se viver de modo bom e adequado".

${ }^{58}$ Cf., por exemplo, o final das comédias plautinas Cásina (Cas. 1017); Menecmos (Men. 1162); Truculento (Truc. 968); ainda Horácio, Arte Poética 155; OLD verbete plaudo, sentido 3b; Cícero, op. cit., 1988, p. 243.

${ }^{59}$ Outra associação entre os $\$ 48$ e 70 é aventada por Powell (Cícero, op. cit., 1988, p. 242): Presumably what is being envisaged in Cicero's image is something like what happened to Turpio Ambivius in the first performance of Terence's Hecyra, as narrated by himself in the prologue. Para uma visão que problematiza tal afirmação do prólogo terenciano, cf. Parker, H. N. Plautus v. Terence: audience and popularity re-examined. American Journal of Philology. Baltimore, vol. CXVII, n. 4, p. 585-617, 1996.
} 


\section{A natureza e o final do espetáculo (§85)}

É apenas na derradeira passagem de theatrum mundi que, tal como na primeira $(\$ 5)$, se volta a enfatizar o papel da natureza:

Quod si non sumus immortalis futuri, tamen extingui homini suo tempore optabile est: nam habet natura, ut aliarum omnium rerum, sic uiuendi modum; senectus autem aetatis est peractio tamquam fabulae, cuius defetigationem fugere debemus praesertim adiuncta sacietate ( $\$ 85$, grifos meus). ${ }^{60}$

Mas, ao mesmo tempo em que se retoma a ideia inicial da natura/ poeta, nesse parágrafo em que se encerra a obra em estudo dá-se continuidade ao tema da finalização da vida expresso no tópos do $\ 70$. Lá, como observamos, enfocara-se o homem e seu dever de cumprir contente qualquer, e quão breve fosse, o papel designado; aqui, apontase a opção, patente ao ser humano, de dar ele mesmo um término à encenação. Interpretando a imagem, pode-se pensar que o roteiro composto pela natureza é, antes que um texto completamente marcado, a ser cumprido ao pé da letra, um script com brechas para alguma improvisação dos atores, ainda que limitada.

\section{Considerações finais: teatro e filosofia}

A atenção ao theatrum mundi em Cato Maior à qual se dedicam as seções anteriores deste estudo leva a constatar que a presença do tópos nesse diálogo filosófico é mais constante e articulada do que as pesquisas tendem a reconhecer. Além disso, a articulação entre as passagens - a qual se mostra um efeito do destaque conferido aos elementos em cada uma, bem como da ordem em que elas aparecem - sugere que tal integração é significativa, o que impede de pensar que a ideia da vida como teatro ali possa se reduzir, como se costuma apontar, a um ornamento que visaria ao mero apelo popular.

\footnotetext{
${ }^{60}$ Cícero, Cato Maior 85: "Pois, caso não venhamos a ser imortais, ainda assim o homem pode optar por fazer cessar seu próprio tempo de viver. Isso porque, assim como a todos os demais assuntos, também ao viver a natureza prescreve um limite. No entanto, a velhice é como a peratuação de uma peça teatral, de cuja exaustão devemos fugir, especialmente quando já alcançada a saciedade.”
} 
Portanto, também aqui, como em outros momentos da história da ideia, a vida como teatro constitui um recurso retórico com efeitos sobre a argumentação do personagem Catão, bem como sobre a interpretação desse texto ciceroniano como um todo. Nesta parte conclusiva, esboçamos uma sugestão, a ser corroborada na continuidade da pesquisa, quanto a efeitos filosóficos derivados do modo como o tópos é empregado nesse diálogo.

Voltemos, pois, a uma de nossas questões iniciais, concernente ao status da natureza na formulação do theatrum mundi na obra em estudo. Após a análise das passagens, fica claro que, em nenhuma das ocorrências do tópos, a natura, enquanto poeta do roteiro da vida, é efetivamente substituída. Além disso, em seu papel de autora do efêmero espetáculo, ela não deixa de ser apresentada positivamente. Para essa posição, bem como para a formulação de liberdade associada a um determinismo (tal qual vista no $\$ 70)$, tem sido apontado um suporte no repertório estoico. ${ }^{61}$ No mesmo sentido, diversos paralelos mais diretos para a imagem do teatro nos passos acima apreciados remetem a textos do estoicismo. ${ }^{62}$

Além disso, lembremos, dentre as filosofias helenísticas, é nessa que um uso simultâneo, melhor dizendo, singularmente integrado de duas imagens de "teatro do mundo" (o homem como espectador e o homem como ator) se evidencia. Como já se apontou, precisamente esse emprego proporciona uma síncrese entre dois aspectos do estoicismo distintos e inseparáveis: ${ }^{63}$ de um lado, a percepção, herdada do ceticismo, ${ }^{64}$ da efemeridade e ilusão da vida; de outro, a submissão do homem a um poder superior e constante - e, lembremos, não raro denominado de "natureza". Tendo isso em vista, a integração entre as imagens de homem espectador/ ator proporcionada pelo desenvolvimento consecutivo das imagens em Cato Maior pode, pois, efetivamente corroborar a visão de estudiosos que defendem o tom estoico como predominante em Cato Maior.

\footnotetext{
${ }^{61}$ Para citar apenas um exemplo recente, cf. Léfevre, op. cit., que considera “programática” a referência a natura e necesssitas no $\$ 4$ (ibidem, p. 48-89).

${ }^{62}$ Cf. para Cato Maior \$70, Cícero De Finibus 3, 45; Sêneca Ep. 77, 20. Powell (Cícero, op. cit., 1988, p. 243) lembra, por exemplo, que, no debate entre peripatéticos e estoicos, os primeiros defendem que uma vida completa seria necessária para a felicidade (cf. Aristóteles NE 1. 109818 sq.), e os segundos não concordam que a qualidade da eudaimonía seja diretamente proporcional ao tempo de vida (Cic. Fin. 3, 45).

${ }^{63}$ Cf. Christian, op. cit.; Radcke, G. Zum "Theatrum mundi”. In: . Tragik und Metatragik. Berlin/ New York: De Gruyter, p. 324-440.

${ }^{64}$ Radcke, op. cit. (nota supra).
} 
Uma dúvida final do protagonista, no entanto, parece apontar para uma outra direção: "Pois se nisto, isto é, pelo fato de crer que as almas humanas são imortais, eu erro, erro de bom grado...” (\$85). ${ }^{65}$ Com reiterado bom humor, o Catão ciceroniano afirma que prefere se equivocar pensando daquela forma visto que, como vantagem do erro, poderia evitar a zombaria dos filósofos mortos (\$85). Aqui, Powell comenta que se tem um "triunfo" do Cícero retórico contra o Cícero filósofo. ${ }^{66}$

No entanto, como sabemos, as obras filosóficas de Cícero tendem a fazer uso também filosófico das técnicas retóricas que, como é notório, nosso autor domina magistralmente. ${ }^{67} \mathrm{Um}$ exemplo, que Powell menciona em outro lugar, ${ }^{68}$ é a argumentação in utramque partem, um recurso que, ao dar espaço a partes opostas, tende, na obra filosófica, a favorecer precisamente a dúvida sobre ambas, podendo levar com isso à isostenia que carateriza a perspectiva cética, ou, como se prefere relacionar a Cícero, acadêmica. ${ }^{69}$

Ora, nesse diálogo em que o protagonista é praticamente o único que se expressa (e defendendo sempre o mesmo ponto de vista, em prol da velhice) não há o recurso à disputa in utramque parte. Penso, porém, que o theatrum mundi teria na obra em apreço um efeito semelhante ao que aquela argumentação teria em diálogos como Sobre a natureza dos deuses (De natura deorum) ou Tusculanas (Tusculanae). Ou seja: a impressão é que, em Cato Maior, precisamente a ênfase nas relações entre teatro e vida, espalhadas pelo texto nas menções a palco, plateia e autores e concentradas no tópos do theatrum mundi, já contribuiriam para esse tom de dúvida resultante, recuperando a raiz cética da metáfora estoica.

\footnotetext{
${ }^{65}$ Quod si in hoc erro, qui animos hominum immortales esse credam, libenter erro, nec mihi hunc errorem quo delector, dum uiuo, extorqueri uolo...(\$85).

${ }^{66}$ Cf. Powell, op. cit., 1988, p. 265: Cicero the rethorician here triumphs over Cicero the Philosopher.

${ }^{67}$ Cf. Powell, op. cit., 1995, p. 21-22: His gifts as an advocate, combined with his literary aemulation of the Platonic dialogue and his adoption of the sceptical methods of the later Academy, enabled him to present alternative points of view with aparently conviction, a deliberate technique that should not be mistaken for vacillation or inconsistency.

${ }^{68}$ Cf. Powell, op. cit., 1995, p. 21-22.

${ }^{69}$ Cf. Powell, op. cit., 1995, p. 20. Em palestra recente em "Ciceronianíssimos! Simpósio de Estudos sobre Cícero" - IEL-Unicamp, 2010, Roberto Bolzani Filho (FFLCH-USP) destaca a retórica como instrumento do ceticismo ciceroniano. O assunto é tratado também em seu estudo anterior (Bolzani Filho, R. Cícero Acadêmico. Kriterion. Belo Horizonte, vol. CII, p. 206-224, 2000); sobre o academicismo em Cícero, cf. ainda Lévy, C. Cicero Academicus. Recherches sur les Académiques et sur la philosophie cicéronienne. Rome: École Française de Rome, 1992.
} 
Desse modo, ao se situar no ponto conclusivo da argumentação, e um pouco antes do último passo de theatrum mundi, a hesitação atribuída por Cícero ao personagem Catão chama atenção para a possibilidade de se relativizar as certezas (supostamente embasadas em experiência e em certo conhecimento da filosofia) que este vinha proferindo. Sob esse ponto de vista, fica mais claro um efeito do emprego do insólito termo peractio ("peratuação"): teatraliza-se não apenas a última parte da vida, como também a última parte do diálogo, a peroratio ("peroração") catoniana.

Aceitar essa possibilidade significa assumir que o emprego da vida como teatro tem efetivamente uma consequência central sobre a argumentação filosófica do diálogo. ${ }^{71}$ A imagem é argumento, nomeadamente: constitui efetivamente mais um recurso retórico e filosófico empregado no diálogo ciceroniano para convidar o leitor a atuar como um espectador do papel ali assumido pelo estadista e distanciando as personae ${ }^{72}$ de autor e personagem, bem como história e argumento - a suspender seu juízo sobre o drama encenado no texto. Se assim é, temos aqui, mutatis mutandis, um estímulo inverso ao que, em 1975, transformou em atores os espectadores da tortura "performática" de Marina Abromović.

\footnotetext{
${ }^{70}$ Sobre a argumentação em prol da imortalidade da alma como peroração do discurso do protagonista, cf. Cícero, op. cit., 1988, p. 9.

${ }^{71}$ Fica claro, pelo que até agora se percebeu, que, para apreender melhor o significado e impacto da imagem da vida teatralizada, bem como das relações entre os tons filosóficos apreensíveis no diálogo do ano 44 a.C., deve-se levar em conta a maneira como o tópos é integrado por nosso autor a convenções comuns a teatro, retórica e diálogo filosófico antigo. Mas este aspecto, bem lembrado por Matheus Trevizam (FALE-UFMG) durante minha exposição em Belo Horizonte, é um tema para um próximo estudo.

${ }^{72}$ Sobre as personae e aspectos dramáticos em outros diálogos de Cícero, tive oportunidade de assistir recentemente à palestra "As personae de Cícero no De finibus e no De natura deorum", proferida por Sidney Calheiros de Lima (FFLCH-USP) no Simpósio de Estudos sobre Cícero do IEL-Unicamp (cf. nota supra). O Cato Maior foi abordado em outras palestras (cuja publicação se prepara) no referido evento: como as de Adriano Scatolin (FFLCH-USP), tendo como contraponto epístolas ciceronianas, bem como, tratando da recepção em Petrarca, a de Bianca F. Morganti (Unifesp). A ela, pela leitura deste texto na versão de janeiro de 2009, agradeço, bem como, mais recentemente, a Carol Martins da Rocha (IEL-Unicamp) e aos editores e revisores da Revista Nuntius Antiquus.
} 


\section{Referências}

ALFONSI, L. La composizione del "De senectute" ciceroniano. Siculorum Gymnasium. Catania, vol. VIII, p. 429-454, 1955/1961.

Sulle fonti del "De senectute". La Parola del passato. Napoli, vol. XLI, p. 121-129, 1955.

AUSTIN, J. L. How to do things with words. The William James lectures delivered at Harvard University in 1955. Oxford: Clarendon Press, 1962.

ASTIN, A. E. Cato and the Greeks. In: . Cato the Censor. Oxford: Clarendon Press, 1978, p. 157-181.

BEARE, W. The Roman stage. London: Methuen, 1955.

BLAIR, A. Jean Bodin and Renaissance science. Princeton (NJ): Princeton University Press, 1997.

BOLZANI FILHO, R. Cícero Acadêmico. Kriterion. Belo Horizonte, v. CII, p. 206-224, 2000.

BOYANCÉ, P. Le Platonisme à Rome: Platon et Cicéron. In: Actes du Congrès de l'Association G. Budé (Tours et Poitiers, 1953). Paris: Les Belles Lettres, 1954, p. 195-222. BUTLER, J. Gender trouble. Feminism and the subversion of identity (subversive bodily acts, IV bodily inscriptions, performative subversions). New York: Routledge 1990.

Performative acts and gender constitution: an essay in phenomenology and feminist theory. In: Case, S.-E. (Org.). Performing feminisms. Feminist critical theory and theatre. Baltimore/ London: Johns Hopkins University Press, 1990, p. 270-282. CANCIK, H.; SCHNEIDER, H. (Org.). Der Neue Pauly. Stuttgart/Weimar: Metzler, 1996 (vol. I); 1997 (vol. III); 2001 (vol. X); 2002 (vol.XII).

CASTELLI, G. "Cato maior de senectute" come Herakleideion. RSC. Torino, vol. XX, p. 5-12, 1972.

CARDOSO, I. T. "Theatrum mundi” na oratória de Cícero. In: Anales del IV Coloquio Internacional: lenguaje, discurso y civilización de Grecia a la modernidad. La Plata: 2006. V. I, p. 32.

"Theatrum mundi": Leben als Nachahmung des Theaters in Ciceros Redekunst". Von Humboldt's introdutory meeting. Leipzig/ Bonn: Von Humboldt, 2006, p. 10 .

. "Theatrum mundi": Philologie und Nachahmung. In: SCHWINDT, J. P. (Org.). Was ist eine Philologische Frage? Frankfurt am Main: Suhrkamp, 2009, p. 82-111. CHRISTIAN, L. G. Theatrum mundi. The history of an idea. (= Diss. Harvard 1969) New York: Garland, 1987.

CÍCERO. Cato Maior de senectute. Catão, o Velho ou Diálogo sobre a velhice. Tradução de M. Kury. Porto Alegre: EDIPUCRS, 1998.

. Cato Maior de senectute. Edited with introduction and commentary by J. G. F. Powell. Cambridge: University Press, 1988.

1963. . Cato Maior de senectute. Edição de M. Faltner. München: Heimeran Verlag, 
CÍCERO. Caton l'ancien (de la vieillesse). Texte établi et traduit par Pierre Wuilleumier. Paris: Les Belles Lettres, 1961.

. De re publica; De legibus; Cato maior de senectute; Laelius de amicitia. Recognovit brevique adnotatione critica instruxit J. G. F. Powell. Oxonii: e Typographeo Clarendoniano, 2006. 1965

. La vecchiezza; L'amicizia. A cura di G. Pacitti. Verona: Arnoldo Mondatori, Pocket, 1997.

"Saber envelhecer" seguido de "Amizade". Trad. P. Neves. Porto Alegre: LPM

CURTIUS, E. R. Europäische Literatur und lateinisches Mittelalter. Bern: Francke, 1948. di PRIMA, A. Cicerone, "Cato Maior" 48 e 53. Paideia. v. XIII, p. 247-251, 1958.

EIGLER, U. Cicero und die römische Tragödie. In: STÄRK, E.; VOGT-SPIRA, G. (Org.). Dramatische Wäldchen. Festschrift für Eckard Lefevre.Zürich/New York: Olms, p. 619-636.

FALCONER, W. A. (Org.). Cicero, De senectute; De amicitia; De diuinatione. London/ Cambridge, Mass.: Harvard University Press, 1971.

FEIG VISHNIA, R. Cicero De senectute 11, and the date of C. Flaminius' tribunate. Toronto. vol. L, n. 2, p. 138-145, 1996.

FISCHER-LICHTE, E. Ästhetik des Performativen. Frankfurt am Main: Suhrkamp, 2004.

FUHRER, T.; ZINSLI, S. (Org.). Gender-Studies in den Altertumswissenschaften. Rollenkonstrukte in antiken Texten. Trier: Wissenschaftlicher Verlag Trier, 2003.

FUHRER, T.; NELIS, D. (Org.). Acting with words. Communication, rhetorical performance and performative acts in Latin literature. Heidelberg: Universitätsverlag Winter, 2010.

FRAENKEL, E. Tulliana. Mus. Helv. Basel, vol. XXIII, p. 194, 1966.

GEFFCKEN, K. A. Comedy in the "Pro Caelio". Leiden: Brill, 1973.

GILDENHARD, I. Paideia Romana. Cambridge: University Press, 2007, p.110; 114-16.

GLARE, P. G. W. (Org.). Oxford Latin Dictionary. Oxford: Clarendon Press, 2007.

GOLDBERG, S. Cicero and the work of tragedy. In: MANUWALD, G. (Org.). Identität und Alterität in der frührömischen Tragödie. Würzburg: Ergon-Verlag, 2000, p. 49-59.

GONZÁLEZ-GARCÍA, J. M.; KONERSMANN, R. "Theatrum mundi”. In: RITTER, J.; GRÜNDER, K. (Org.). Historisches Wörterbuch der Philosophie. Basel: Schwabe, 1998. Vol. X, p. 1051-1054.

GRIMAL, P. Dictionnaire de la mythologie grecque et romaine. Paris: PUF, 1963.

JOCELYN, H. D. Diatribes and sermons. Liverpool Classical Monthly. Liverpool, vol. VII, p. 3-7, 1982.

KINSTRAND, J. F. Bion of Borysthenes. Stockholm: Almqvist Wiksell, 1976, p. 116$17 ; 204-12$.

KOKOLAKIS, M. The dramatic simile of life. Athens: Boukouris, 1960. 
LEFÈVRE, E. Der "Tithonos" Aristons von Chios und Ciceros "Cato". Hermes. Stuttgart, vol. CXXXV, p. 43-65, 2007.

LÉVY, C. Cicero Academicus. Recherches sur les Académiques et sur la philosophie cicéronienne. Rome: École Française de Rome, 1992.

MACKENDRICK, P. (Org.). The philosophical books of Cicero London: Duckworth, 1989.

MANFREDINI, M. Argantonio re di Cadice e le fonti del "Cato Maior" ciceroniano. RFIC. Torino, vol. XCVIII, p. 278-291, 1970.

NOVARA, A. Le vieux Caton aux champs ou le plaisir exceptionnel de l'agriculture pour un sage vieillard. In: LE BONNIEC, H.; VALLET, G. Mélanges P. Wuilleumier. Paris: Les Belles Lettres, 1980, p. 261-68.

OLTRAMARE, A. Les origines de la diatribe romaine. Genebra: Payot, 1926.

PARKER, H. N. Plautus v. Terence: audience and popularity re-examined. American Journal of Philology. Baltimore, vol. CXVII, n. 4, p. 585-617, 1996.

PIANEZZOLA, E. Politica e poesia in Cicerone, "Le Fenicie" di Euripide. Ciceroniana. Roma, v. V, p. 167-172, 1984.

POWELL, J. G. F. (Org.). Cicero the philosopher. Twelve papers. Oxford: Clarendon Press, 1995.

ROMANO, A. Humor y discurso politico. Phaos. Campinas, v. I, p. 159-169, 2001.

RUCH, M. Le préambule dans les oeuvres philosophiques de Cicéron. Essai sur la genèse de l'art du dialogue. Paris: Les Belles Lettres, 1958.

SARISBERIENSIS,J. Policraticus I-IV.Edidit Katherine Keats-Rohan. Turnholti: Brepols, 1993.

SHAKESPEARE, W. As you like it. Ed. by Alan Brissenden. Oxford: Clarendon Press, 1993.

SPAHLINGER, L. Tulliana simplicitas. Zu Form und Funktion des Zitats in den philosophischen Dialogen Ciceros. Göttingen: Vandenhoeck und Ruprecht, 2005.

STRATI, R. Il proemio del "Cato Maior" di Cicerone. Lexis. Trento, v. XVIII, p. 193-212, 2000 .

STROH, W. Cicero, Redner, Staatsmann, Philosoph. München: Beck, 2008.

TORNOS, A. M. La historia en el diálogo "De senectute”. Humanidades. v. V, p. 272280, 1953.

VENINI, P. La vecchiaia nel "De senectute" di Cicerone. Athenaeum. Pavia, v. XXXVIII, 98-117, 1960.

RADCKE, G. Zum "Theatrum mundi”. In: . Tragik und Metatragik. Berlin/ New York: De Gruyter, p. 324-440.

THESAURUS Linguae Latinae. Leipzig: Teubner, 1900-2009.

ZILLINGER, W. Cicero und die altrömischer Dichter. Würzburg: Staudenraus, 1911. 